\title{
The Effectiveness of the Physical Education Learning Model Using the TPSR Approach for Character Building of Elementary Students (Game of "Train Ride")
}

\author{
Hermawan Pamot Raharjo ${ }^{1}$, Tandiyo Rahayu ${ }^{2}$, Mugiyo Hartono ${ }^{3}$, Sulaiman $^{4}$, Donny Wira \\ Yudha Kusuma ${ }^{5}$ \\ \{hermawan_pamot@gmail.unnes.ac.id, tandiyorahayu@mail.unnes.ac.id, hartonofik@mail.unnes.ac.id \}
}

Department of Physical Education, Faculty of Sport Science, Universitas Negeri Semarang $1,2,3,4,5$

\begin{abstract}
The aim of the study is for students to be able to demonstrate appropriate behavioral and activity choices through this type of teaching, and will show greater concern for the well-being, security, and quality of their colleagues' experiences using TPSR of Game of Train Ride. The method using R\&D design of Borg \& Gall, and 24 students from 2 school participated in this study. The result showed that level 0 shows a percentage of $4.17 \%$ or numbered 1 student, at level 1 shows the percentage of $25.00 \%$ or numbered 6 students, at level 2 shows a percentage of $37.50 \%$ or numbered 9 students, at level 3 shows percentage $29.17 \%$ or amounting to 7 students and at level 4 shows a percentage of $4.17 \%$ or numbering 1 student. An increase in the activeness of children in playing, this is because they have been given a role in playing having increased responsibility in leading their friends so that the essence of a child when given assignment responsibilities will do well
\end{abstract}

Keywords: physical education, character building, TPSR

\section{Introduction}

The Personal and Social Responsibility model (TPSR) was invented on 1970's by Donald Hellison, with the aim of making young people at risk of social environment in good experiences to support the development of their personal, social skills and responsibilities, both in sports as in life $[1,2]$.

The model of learning about responsibility as a burden or moral responsibility related to oneself and others, therefore, the values associated with personal responsibility are effort and autonomy; and the values associated with social responsibility are respect for other feelings and rights, social empathy and sensitivity [1]. The core of the TPSR model is to consider that young people become efficient individuals in their social context, they must learn how to be responsible for themselves and for others. Those who participated in the TPSR model learned how to develop personal and social responsibility in stages, experiencing behaviors and attitudes that would help them become responsible people.

There are a number of studies that have questioned the model of application and accountability Hellison's responsibility model, produce broad basic theories and empirical comparisons, which place them as positive development programs through physical activity 
and sports [3-6]. However, since the review carried out by Baldock et all (2017) in a previous edition, there are no other recent research articles that have been published. This article, emerges from this shortcoming, with the aim of offering the latest review of research conducted in the US and Spain, about programs based on the TPSR model.

The technological maturity achieved in the current millennial era has had a tremendous impact on social life both positively and negatively, and the process of education in the family is a priority to filter out the negative characters that arise [8]. Education plays a very important role because Education is an endless process that will determine the character of the nation in the present and future, a nation will be a nation of good character or a nation with bad character, depending on the quality of education that can shape the character of the nation these $[9,10]$.

Character education does not just teach students right and wrong, but more than that, character education instills habits (habituation) about the good so that students understand, are able to feel, and want to do good. So, character education carries the same mission with moral education or moral education $[11,12]$.

Changes in children's character are reflected in changes in attitudes that occur today, including: Children love to be alone in the room until evening after school so that it greatly reduces the process of interaction between families, and reduces their movement activities, and the most terrible thing is that students are involved in brawls between schools, students are involved in a brawl from football fans, bullying fellow friends and so on $[13,14]$. Students are involved in behavior that is not in accordance with their age making parents worry about their children's future means that what students do outside of school sometimes reflects a negative attitude [15]. This phenomenon is very interesting to study and find the right solution because almost all children of student age are spent at school, so the role of education is very important to change children's attitudes towards better abilities. In this study the concept of "Role Playing" in playing "Train Ride" was more focused on the formation of personal attitudes and social attitudes in students during the lesson, because children are invited to play while carrying out tasks that have been mutually agreed upon [16, 17].

Donald R Hellison (2011) said: Discussing the level of responsibility in the TPSR approach is to help children be more personally responsible and socially responsible by instilling TPSR ideas and strategies in physical activity. As a cumulative development, students learn that each level is built and covers all the more low levels [18,2].

Table 1. Level of Teaching Personal Social Responsibility

\begin{tabular}{cl}
\hline Level & \multicolumn{1}{c}{ Components } \\
\hline I & $\begin{array}{l}\text { Respecting the right and feeling of others; Self-control; The right to } \\
\text { peaceful conflict resolution; The right to be included }\end{array}$ \\
II & $\begin{array}{l}\text { Participation and effort; Self-motivation; Exploration of effort and } \\
\text { new tasks ; Courage to persist when the going gets tough }\end{array}$ \\
III & $\begin{array}{l}\text { Self-direction; On-task independence; Goal-setting progression; } \\
\text { Courage to resist peer pressure } \\
\text { IV }\end{array}$ \\
& $\begin{array}{l}\text { Helping others and leadership; Caring and compassion; Sensitivity } \\
\text { and responsive } \\
\text { Onner strength } \\
\text { Trying these ideas in other areas of life being a; role model }\end{array}$ \\
&
\end{tabular}


From this background it is clear that teachers really need practical teaching guidelines to be used in the basic motion learning process in schools and have a context that prioritizes character building for children. Characters formed early on, children will be able and able to determine the direction of their lives and prepare them to meet life full of challenges. In addition to answering the problem it is necessary to develop a learning material development program for Physical Education for the lower classes that is tailored to the objectives of PE, namely developing attitudes / character, developing knowledge and developing students' skills. In this case the researcher will develop basic motion material with the TPSR (Teaching Personal and Social Responsibility) model into the lower learning process (Game of Train Ride/GTR). The TPSR model has a strong foundation in humanism to create a studentcentered approach with the aim of facilitating the development of students' personal and social responsibilities. The uniqueness of this model lies in focusing on setting goals for student participation in the classroom. Another important aspect of this model is to encourage students to be more reflective in decision making and provide access for students to express their opinions, interests, and feelings. The aim is for students to be able to demonstrate appropriate behavioral and activity choices through this type of teaching, and will show greater concern for the well-being, security, and quality of their colleagues' experiences [19]. When it can be implemented properly this program will be able to shape the attitude of personal responsibility and social responsibility of the participants, and the role of the instructor / teacher also plays an important role in creating such a situation, so that the TPSR model can be integrated into the learning program at school.

\section{Methods}

Modification of research and development (R \& D) of Borg and Gall is used to do this study [20, 21]. There are six stages in this study; (1) analysis required; (2) design; (3) prototype; (4) testing; (5) revision; and (6) validity and reliability test. First, analysis required in the development of GTR. Focus group discussion is used to collect data in this stage. Second, design of instrument by selected version modification, which was the main choice as the result of focus group discussion at the previous stage of analysis requirement and application of computerized technology. Third, creating a prototype in accordance with the design intended in previous stage, where the GTR was executed in one class. Fourth, after the product is completed, the next stage is to examine the design of badminton agility test. 24 students from the elementary school are served as subject for this study and three PE experts are assigned to assess the effectiveness of GTR. This experiment is used to anticipate any possible errors, as well as to analyze the obstacles that may be encountered and tried to mitigate these constraints. Moreover, the next stage was product revisions; it aims to improve the product before the product is ready to be used. Revisions were based on review and input from experts and PE teachers, as well as the test results.

\section{Results}

From the results of preliminary observations obtained data about the characteristics of lower class elementary school Sukorejo 02 Gunungpati City, Semarang are: the number of 
students in one class is 24 students, and each student is given a number to observe the character in one lesson and the initial data is obtained as follows:

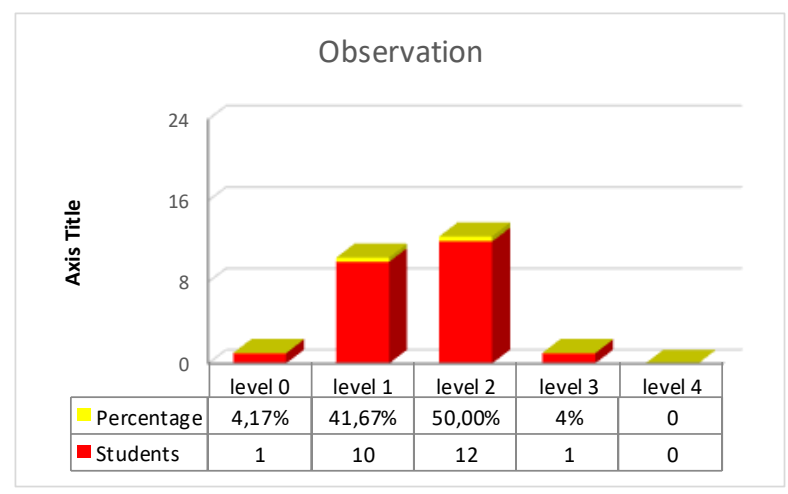

Fig. 1. Preliminary data of student's characteristics

From figure 1 it can be explained that level 0 shows a percentage of $4.17 \%$ or numbered 1 student, at level 1 shows a percentage of $41.67 \%$ or numbered 10 students, at level 2 shows a percentage of $50 \%$ or numbered 12 students, at level 3 shows a percentage $4.17 \%$ or numbered 1 student and at level 4 shows a percentage of $0 \%$ or totaling 0 students.

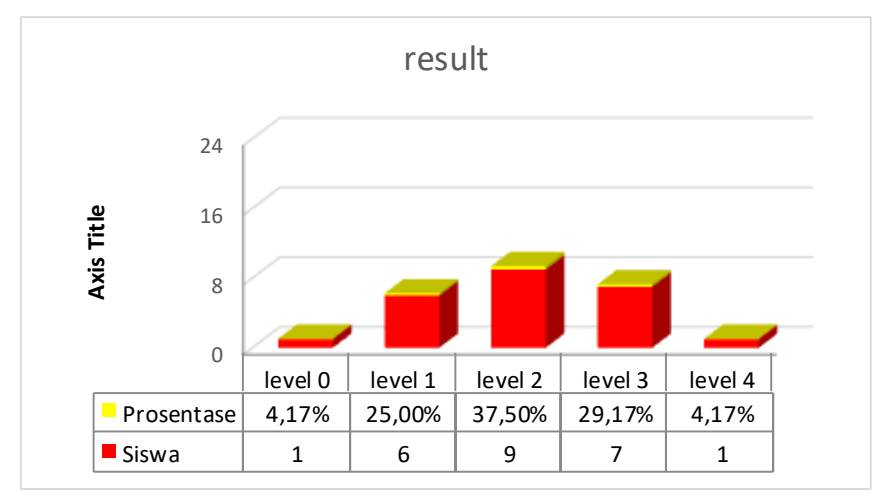

Fig. 2. Data result of student's characteristics after using GTR

From figure 2 it can be explained that level 0 shows a percentage of $4.17 \%$ or numbered 1 student, at level 1 shows the percentage of $25.00 \%$ or numbered 6 students, at level 2 shows a percentage of $37.50 \%$ or numbered 9 students, at level 3 shows percentage $29.17 \%$ or amounting to 7 students and at level 4 shows a percentage of $4.17 \%$ or numbering 1 student.

The results of the value of knowledge obtained through authentic assessment are carried out using oral techniques, namely conducting direct question and answer questions from the introduction, core, and closing process using interview guideline instruments that are adjusted to the level of development and growth of first grade elementary school students. The graph of the assessment results is as follows: 


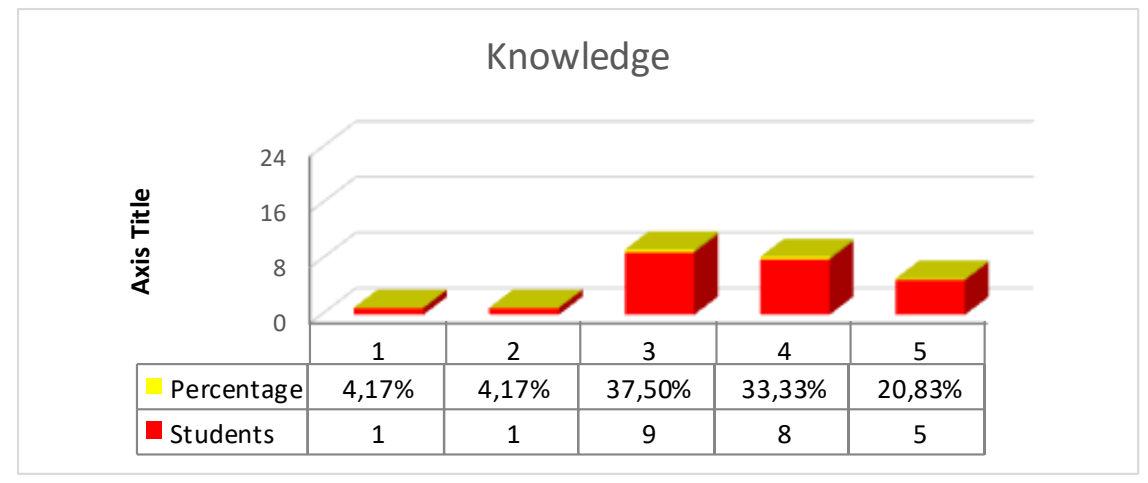

Fig. 3. Knowledge score of students

The results of the knowledge assessment show that all students are able to get scores with the distribution as above, so it can be concluded that this game is able to explore the ability of students' knowledge and be able to explore the courage of students to speak up in front of friends and teachers.

The results of skill scores are obtained through authentic assessment conducted by using direct observation techniques, namely by directly observing the progress of the student's learning process starting from the preliminary, core, and closing processes using observation guideline instruments that are adjusted to the level of development and growth of elementary school students. The graph of the assessment results is as follows:

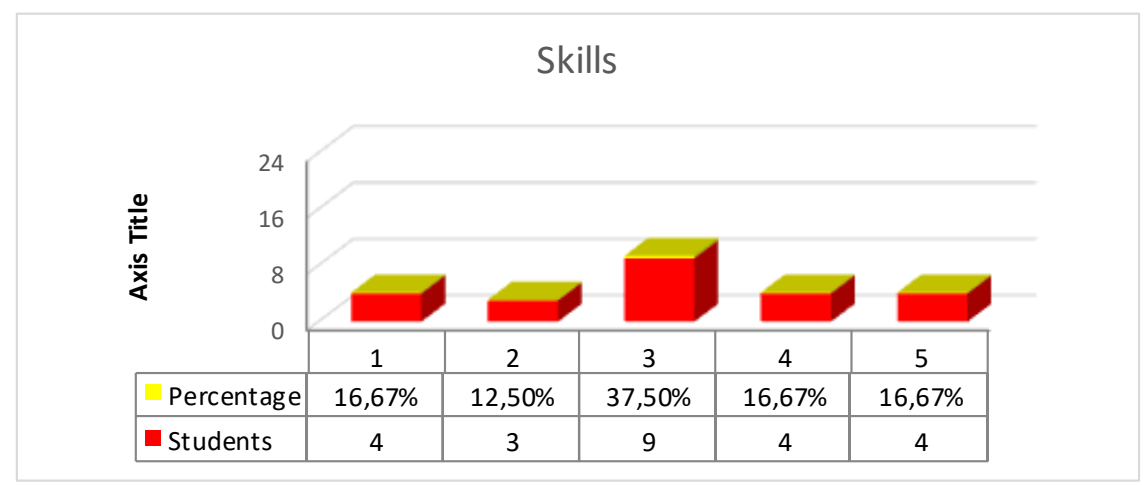

Fig. 4. Skill score of students

The results of the skills assessment show that all students are able to get a value with the distribution as above, so it can be concluded that this game is able to explore the locomotors abilities of students. 


\section{Discussion}

At Level 0 (irresponsible category), the results of the initial observations contained a score of 1 and the results of the study showed a score of 1 , so it was concluded that there was no change in the character of the child, because the process of action was only 1 lesson, so changing a child's character is not possible in a short time [22]. from the observations it was seen that there was one child who tended to disturb his friends in playing, when this child was given a role as a train member he always refused and refused to play according to the rules. It is not easy to change a child's character in just a short time because the character is strongly influenced by previous education, including the influence of family education (home habits) and the child's playing environment for a long time $[23,24]$, so repetitive actions need to be taken so that accustomed to being more responsible $[2,19]$

At Level 1, from the initial observation the score of 10 and the results of the study showed a score of 6 , so it was concluded that there was an increase in changes in the character of the child, this is because there were 4 children experiencing changes in the level above. This level is the character of children who are passive but do not like to disturb friends. The results of the observations showed an increase in the activity of children in play, this was because they had never played before, with interesting media and regulations that made them motivated to try to play actively. Whereas 6 children did not experience change and there was still no high motivation to try, this was because the movement of children was influenced by two factors, namely internal and external, internal is the motivation of the child's own self which is influenced by the physical condition and environment of the family that shapes it. The solution for these six passive children is to increase the level of attention and different treatments so that children feel guided.

At Level 2, from the initial observation the score of 12 and the results of the study showed a score of 9, so it was concluded that there was an increase in changes in the character of the child, this is because there were 3 children who experienced changes in the level above. Level 2 is the character of children who are active but in playing still have to be watched by the teacher. The results of the observations show an increase in the activeness of 3 children in playing, this is because they have been given a role in playing having increased responsibility in leading their friends so that the essence of a child when given assignment responsibilities will do well. Whereas 9 children did not experience a change in character because they did not get the role of being the group leader causing the level of responsibility not yet apparent in the assessment.

At Level 3, from the initial observation the score 3 and the results of the study showed a score of 7 , so it was concluded that there was an increase in the change in character of 4 children, this is because there were 4 children experiencing changes in the level above. This level is an independent child's character. When children are given roles and responsibilities in playing they are able to actualize themselves in understanding the role so that in playing they are able to do it with totality.

At Level 4, from the results of the initial observation the score 0 and the results of the study showed a score of 1 , so it was concluded that there was an increase in change in character 1 child, this is because there was one child experiencing a change in the level above. This level is the character of children who care about friends. When getting a role as chairman, the level of concern for friends arises and likes to help friends, for example: fix when there is equipment that falls, fix the position of friends, etc. 


\section{Conclusions}

There was no change in the character of the child, because the process of action was only 1 lesson, so changing a child's character is not possible in a short time if in their family uneducated but for the family with good education they will be more responsibility. The character of children who are active but in playing still has to be watched by the teacher. The results show an increase in the activeness of children in playing, this is because they have been given a role in playing having increased responsibility in leading their friends so that the essence of a child when given assignment responsibilities will do well 


\section{References}

[1] D. H. \& T. Martinek, "Learning Responsibility through Sport and Physical Activity," in Positive Youth Development Through Sport, 2018, pp. 180-190.

[2] D. Hellison, "THEMES FOR TEACHING PERSONAL AND SOCIAL RESPONSIBILITY.," in In Hellison, Don |a University of Illinois at Chicago (ed.), Teaching responsibility through physical activity. 2nd ed, Champaign, Ill., Human Kinetics, c2003, p.15-23;155-161., 2003.

[3] J.-E. Romar, E. Haag, and B. Dyson, "Teachers' experiences of the TPSR (Teaching Personal and Social Responsibility) Model in Physical Education,” Ágora para la EF y el Deport., vol. 17, no. 3, pp. 202-219, 2015.

[4] B. Gordon, J. M. Jacobs, and P. M. Wright, "Social and Emotional Learning Through a Teaching Personal and Social Responsibility Based After-School Program for Disengaged Middle-School Boys," J. Teach. Phys. Educ., vol. 35, no. 4, pp. 358-369, 2016.

[5] M. W. Metzler, "Teaching Personal and Social Responsibility," in Instructional Models for Physical Education, 2011, pp. 391-418.

[6] N. I. Rahayu, A. Suherman, and Y. Ruhayati, "Physical Education - Based Teaching Personal Social Responsibility," 2018, pp. 834-837.

[7] R. Baldock, B. Gordon, M. Hemphill, and C. Sanders, "Introducing Teaching Personal and Social Responsibility into physical education," Act. Heal. J., vol. 24, no. 4, pp. 21-24, 2017.

[8] C. Z. Harun, "Manajemen pendidikan karakter.," J. Pendidik. Karakter, 2015.

[9] Sharifah Nor Puteh and A. Ali, "Pendekatan Bermain Dalam Pengajaran Bahasa Dan Diterasi Bagi Pendidikan Prasekolah,”J. Pendidik. Bhs. Melayu 1, 2011.

[10] Aliza Ali, Sharifah Nor Puteh, and Zamri Mahamod, "Isu dan kekangan melaksanakan pendekatan melalui bermain dalam pengajaran bahasa bagi kanak-kanak prasekolah,” Pros. Semin. Int. Pendidik. Ke-6. Kual. dan Kecemerl. Dalam Pendidik., 2013.

[11] H. Supranoto, "IMPLEMENTASI PENDIDIKAN KARAKTER BANGSA DALAM PEMBELAJARAN SMA,” PROMOSI (Jurnal Pendidik. Ekon., 2015.

[12] Soedjatmiko, "Membentuk Karakter Siswa Sekolah Dasar Menggunakan Pendidikan Jasmani Dan Olahraga,” J. Phys. Educ. Heal. Sport http//journal.unnes.ac.id/nju/index.php/jpehs, vol. 1, no. 1, pp. 23-27, 2015.

[13] E. R. Fauziah, "Pengaruh Game Online Terhadap Perubahan Perilaku Anak Smp Negeri 1 Samboja," lmu Komun., vol. 1, no. 3, pp. 1-16, 2013.

[14] M. M. Pandie and I. T. J. Weismann, "Pengaruh Cyberbullying Di Media Sosial Terhadap Perilaku Reaktif Sebagai Pelaku Maupun Sebagai Korban Cyberbullying Pada Siswa Kristen SMP Nasional Makassar,” J. Jaffray, vol. 14, no. 1, pp. 43-62, 2017.

[15] A. E. Musthafa, "Pengaruh Intensitas Bermain Game Online dan Pengawasan Orang Tua Terhadap Perilaku Agresif Anak," junal skripsi, vol. 1, no. 1, pp. 1-13, 2015.

[16] H. Nur, "Membangun Karakter Anak Melalu Permainan Anak Tradisional," Membangun Karakter Anak melalui Permainan Anak Tradis., vol. 3, no. 1, pp. 1-8, 2013.

[17] I. Khasanah, A. Prasetyo, and E. Rakhmawati, "Permainan Tradisional Sebagai Media Stimulasi Aspek Perkembangan Fisik Motorik Anak Usia Dini,” Penelit. PAUDIA, vol. 1, no. 1, pp. 91-105, 2011.

[18] D. Hellison, Teaching personal and social responsibility. 1995.

[19] D. Watson and B. Clocksin, Using Physical Activity and Sport to Teach Personal and Social Responsibility. 2013.

[20] \& B. Gall, Gall, "Chapter 8, Questionnaire \& Interview Data," in Collecting research data with questionanair and interviews, 1996.

[21] J. W. Creswell, Educational research: Planning, conducting, and evaluating quantitative and qualitative research, vol. 4. 2012.

[22] D. Dupri, "Differences between Teaching Personal Social Responsibility (TPSR) Model and Cooperative Learning Model in Improving Students Tolerance and Responsibility," J. Pendidik. Jasm. DAN OLAHRAGA, vol. 4, no. 1, 2019.

[23] H. National Collaborating Centre for Mental, "Psychological interventions and parent 
training," in Attention Deficit Hyperactivity Disorder: Diagnosis and Management of ADHD in Children, Young People and Adults., vol. NICE Clini, 2009, p. Chapter 7.

[24] H. Family, "Parent - Teacher Conference Tip Sheets for Principals , Teachers , and Parents Parent - Teacher Conference Tip Sheets," Education, no. June, 2009. 